\title{
PERAHU NELAYAN MENGGUNAKAN JERIGEN PLASTIK BEKAS UNTUK MENINGKATKAN KESEJAHTERAAN NELAYAN
}

\author{
Purwo Joko Suranto', Bambang Sudjasta ${ }^{2}$ \\ Program Studi Teknik Perkapalan, Universitas Pembangunan Nasional "Veteran" Jakarta, Jakarta Selatan 12 \\ email ${ }^{1}:$ jekdoank@gmail.com
}

\begin{abstract}
Abstrak
Perahu nelayan adalah suatu sarana yang dapat mengapung di air yang digunakan oleh para nelayan untuk mencari dan menangkap ikan di sungai maupun di laut. Perahu nelayan merupakan sarana yang paling penting bagi para nelayan untuk digunakan mencari dan menangkap ikan, tanpa adanya perahu maka nelayan tidak bisa mencari nafkah untuk keluarganya. Di Indonesia cukup banyak sekali masyarakat perkampungan nelayan, dikarenakan Indonesia merupakan negara kepulauan dimana setiap pulau dikelilingi oleh lautan. Mereka tersebar dan hidup bermukim di daerah-daerah pinggiran pantai atau pesisir pantai di seluruh wilayah kepulauan Indonesia. Mahalnya harga perahu nelayan, sehingga banyak nelayan yang tidak mempunyai perahu sendiri. Kebanyakan mereka bekerja pada juragan-juragan kapal sebagai buruh nelayan, dengan demikian penghasilan mereka tidak mencukupi untuk memenuhi kebutuhan keluarga. Dilain pihak banyak sekali jerigen-jerigen plastik bekas tempat minyak yang tidak dimanfaatkan sehingga bisa menjadi limbah, jerigen-jerigen plastik inilah yang akan dimanfaatkan untuk pembuatan perahu nelayan. Tentunya didesain dan dihitung kekuatan serta stabilitas dari perahu tersebut, sehingga terjamin keselamatan nelayan dalam mencari ikan di laut. Ukuran pokok Perahu yaitu Panjang Perahu Keseluruhan (Loa) $=3,80 \mathrm{~m}$, Panjang Perahu antara Garis Tegak $(\mathrm{Lpp})=$ $3,40 \mathrm{~m}$, Sarat Perahu $(\mathrm{T})=0,400 \mathrm{~m}$, Lebar Kapal $(\mathrm{B})=0,858 \mathrm{~m}$, Kecepatan dirancang $=6$ knot Sesuai dengan besarnya kecepatan perahu 6 knot maka didapat Hambatan Perahu adalah 840,83 Newton (N) serta Besarnya Effektif Horse Power (EHP) perahu tersebut adalah 3,48 Horse Power (HP). Berdasarkan EHP yang didapat maka dapat dicari besarnya Break Horse Power (BHP) perahu tersebut, setelah melalui perhitungan berdasar dari EHP tadi maka didapatkan besarnya BHP mesin adalah 6,931 HP kemudian dicari mesin yang ada dipasaran didapat BHP mesin 7 HP. Besarnya muatan perahu dihitung sesuai displasemen perahu dimana Displasemen $=$ DWT + LWT dimana unsur muatan terdapat pada DWT sehingga setalah melalui perhitungan maka didapat hasil muatan yang bisa diangkut oleh perahu tersebut sebesar $655,5 \mathrm{~kg}$. Stabilitas perahu pada kondisi muatan kosong (Empty Load) sebagaimana maupun pada kondisi muatan penuh (Full Load) menunjukan bahwa stabilitas perahu nelayan tersebut sangat baik artinya apabila perahu oleng atau miring akibat ombak, angin atau muatan maka perahu tersebut dapat kembali keposisi tegak sehingga perahu tidak tenggelam, maka aman digunakan oleh nelayan.
\end{abstract}

Kata kunci: jerigen, nelayan, perahu, stabilitas

\section{PENDAHULUAN}

Perahu Nelayan sebagaimana diperlihatkan pada gambar 1 adalah suatu sarana yang dapat mengapung di air yang digunakan oleh para nelayan untuk mencari dan menangkap ikan di sungai maupun di laut. Perahu nelayan merupakan sarana yang paling penting bagi para nelayan untuk digunakan mencari dan menangkap ikan, tanpa adanya perahu maka nelayan tidak bisa mencari nafkah untuk keluarganya. Di Indonesia cukup banyak sekali masyarakat perkampungan nelayan, dikarenakan Indonesia merupakan negara kepulauan dimana setiap pulau dikelilingi oleh lautan. Mereka tersebar dan hidup bermukim di daerah-daerah pinggiran pantai atau pesisir pantai di seluruh wilayah kepulauan Indonesia. Mata pencarian mereka adalah mencari dan menangkap ikan untuk memenuhi kebutuhan hidup keluarga sebagaimana terlihat pada gambar 1 . 


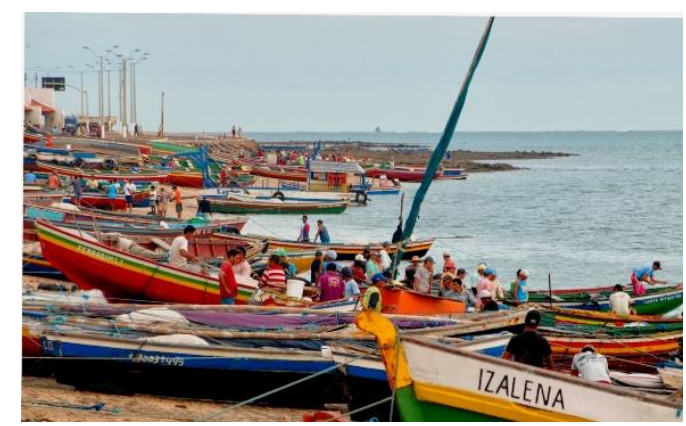

Gambar 1. Perahu Nelayan (Sumber:

http://www.panoramio.com, 5 Juni 2017)

Nelayan tidak punya perahu ibarat petani tanpa sawah, sehingga hanya bisa ikut dan bekerja pada juragan-juragan yang mempunyai perahu. Nelayan-nelayan yang seperti itu masih banyak sekali di Indonesia, sebagaimana survey dan pengamatan serta wawancara yang sudah saya lakukan di daerah perkampungan nelayan gambar 2, di daerah Jawa Barat khususnya di kecamatan Kasemen Banten maupun di Kecamatan Labuan Pandeglang Banten. Dikarenakan harga perahu nelayan yang terlalu mahal maka sebagian besar masyarakat nelayan didaerah tersebut belum mempunyai perahu sendiri untuk mencari nafkah, sehingga para nelayan tersebut masih banyak sebagai nelayan pekerja atau nelayan buruh artinya mereka dalam mencari dan menangkap ikan ikut atau bekerja pada juragan-juragan yang mempunyai perahu. Penghasilan merekapun sangat minim sehingga banyak sekali para nelayan di daerah-daerah perkampungan nelayan di sepanjang wilayah pesisir pantai Indonesia sebagaimana terlihat pada gambar 2 dimana kondisinya sangat memprihatinkan dan mereka tergolong masyarakat keluarga miskin.

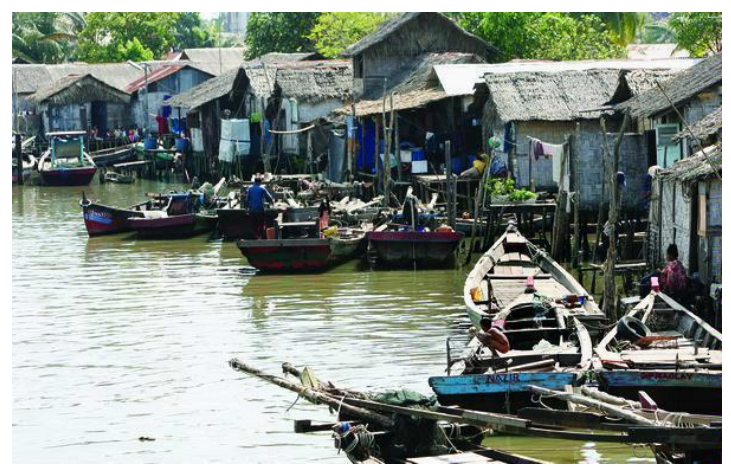

Gambar 2. Perkampungan Nelayan di Wilayah Pesisir Pantai Indonesia

(Sumber: http://lautindonesia.com, http://www.panoramio.com,5 Juni 2017)

Dengan keadaan para nelayan yang demikian maka harus dicari solusinya bagaimana agar para nelayan bisa mempunyai perahu sendiri sehingga dapat menafkahi keluarganya dengan layak. Untuk hal tersebut maka saya mencoba untuk merancang dan membuat perahu nelayan yang harganya dapat terjangkau oleh para nelayan tersebut. Agar harga perahu nelayan bisa ditekan semurah mungkin maka perlu dicari bahan alternatif dengan menggunakan material atau bahan yang harganya murah tetapi kekuatannya bagus. Bahan atau material yang saya gunakan disini adalah merupakan bahan limbah atau jerigen bekas tempat minyak yang terbuat dari plastik atau sering disebut jerigen plastik.

\section{Metodologi Penelitian}

Metodologi penelitian sebagaimana diperlihatkan pada flowchart gambar 3, identifikasi yang dilakukan adalah dengan mengadakan survey langsung ke perkampungan nelayan di desa Caringin kecamatan Labuan Kabupaten Pandeglang Provinsi Jawa Barat. Masyarakatnya disana ternyata banyak banyak nelayan buruh artinya mereka bekerja ikut perahu nelayan orang lain atau ikut juragan-juragan pemilik perahu nelayan, dikarenakan mereka tidak mempunyai perahu nelayan sendiri sebab harga perahu sangat mahal.

Menentukan ukuran serta spesifikasi jerigen bekas yang akan digunakan untuk membuat perahu nelayan dan jumlah yang dibutuhkan untuk ukuran pokok perahu nelayan yang akan di desain.

Mendesain lambung (hull) perahu nelayan dengan menggunakan jerigen plastik bekas sesuai ukuran pokok perahu yang akan di desain. Desain perahu tersebut menggunakan bantuan software maxsurf.

Menghitung displasemen atau berat perahu yang akan di desain yang mana Displasemen $=$ LWT + DWT dimana LWT (Light Weight Ton) adalah berat perahu kosong sedangkan DWT (Dead Weight Ton) adalah berat atau bobot mati perahu.

Mengecek apakah perahu stabilitasnya baik atau tidak kalau stabilitasnya baik maka bisa lanjut untuk menghitung hambatan perahu, apabila belum stabil maka harus kembali ke ukuran pokok perahu diperbaiki.

Setelah stabilitas perahu baik maka dihitunglah hambatan total perahu dengan rumus sebagai berikut Hambatan Total $=$ Hambatan gesek + Hambatan sisa $(\mathrm{Rt}=\mathrm{Rf}+\mathrm{Rs})$.

Kemudian dengan didapatnya hambatan total perahu maka bisa dihitung dan ditentukan power BHP mesin atau power EHP mesin perahu yang dibutuhkan.

Selanjutnya adalah pembuatan model atau prototipe perahu nelayan dengan menggunakan jerigen plastik bekas. 


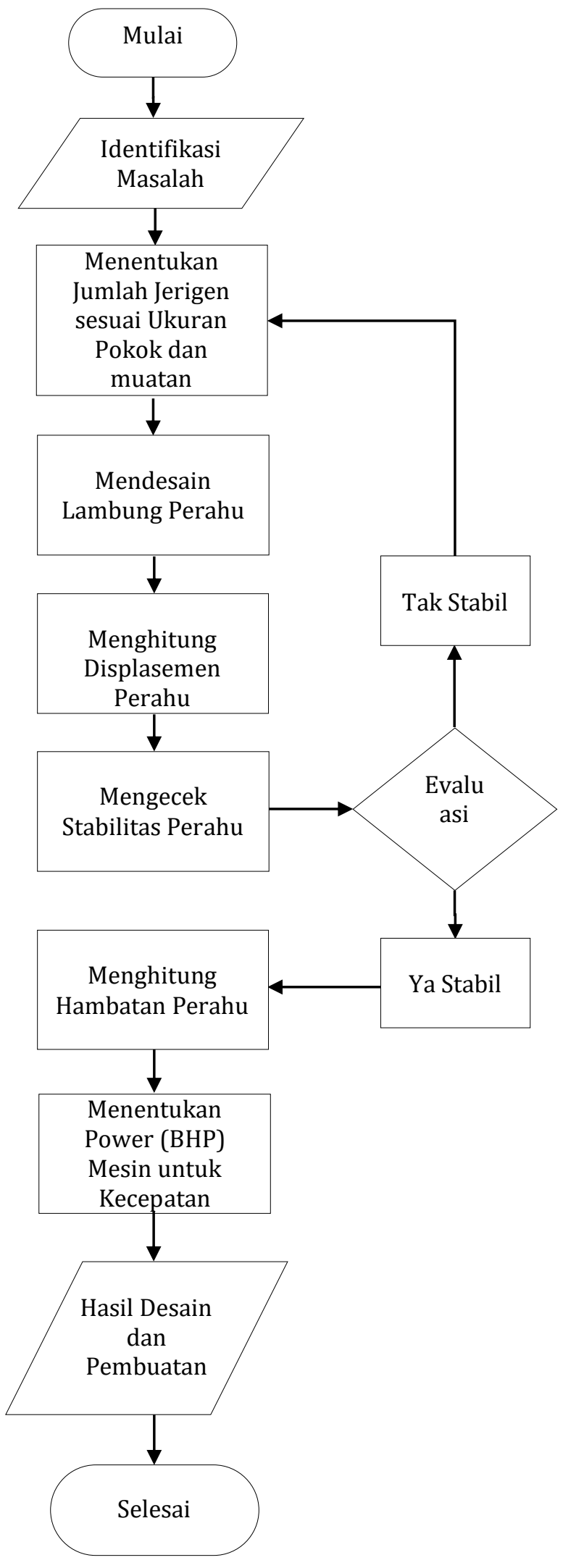

Gambar 3. Diagram Alir Metodologi Penelitian.

DATA, HASIL dan LUARAN YANG DICAPAI. Data Wilayah Survey.
Survey dilakukan di perkampungan nelayan desa Caringin Kecamatan Labuhan Kabupaten Pandeglang Provinsi Banten adapun peta lokasi sebagaimana terlihat pada gambar 4 .

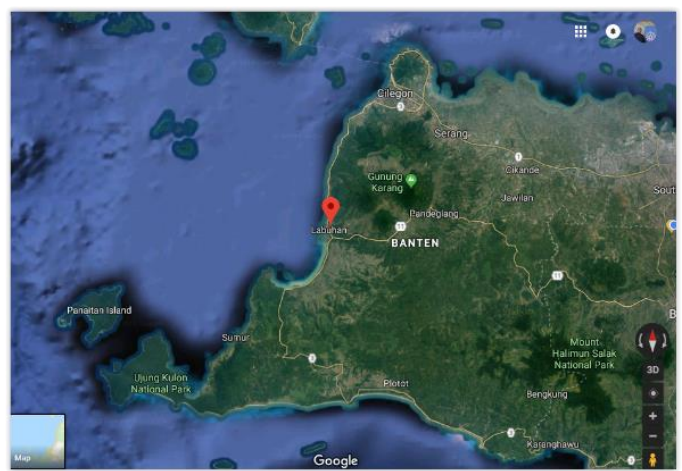

Gambar 4. Wilayah Caringin (http://googlemap.com,7 Agustus 2018)

Tepatnya di sebuah desa disepanjang sungai Caringin sebagaimana dapat dilihat pada gambar 4, disitu penduduk atau warganya sebagian besar mata pencahariannya adalah nelayan. Sungai caringin ini adalah sungai yang berhubungan langsung dengan laut lepas. Masyarakat di daerah tersebut sebagian besar mata pencahariannya adalah sebagai nelayan.

Perahu nelayan didaerah tersebut sebagian besar menggunakan perahu cadik, gambar 5 dan perahu yang bukan cadik, gambar 6 . Perahu-perahu yang digunakan kebanyakan berukuran 5 sampai 7 meter yang terbuat dari bahan kayu.

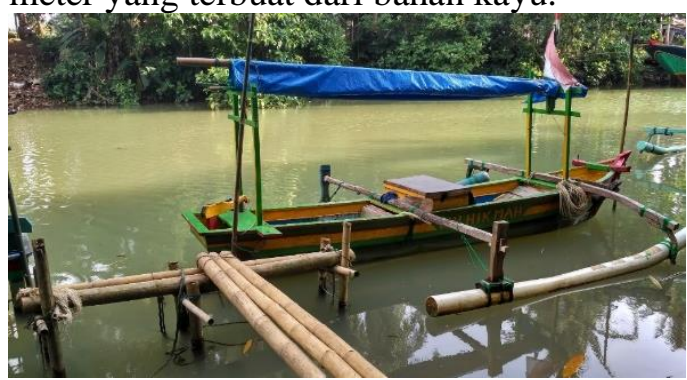

Gambar 5. Perahu Nelayan Cadik di Sungai Caringin

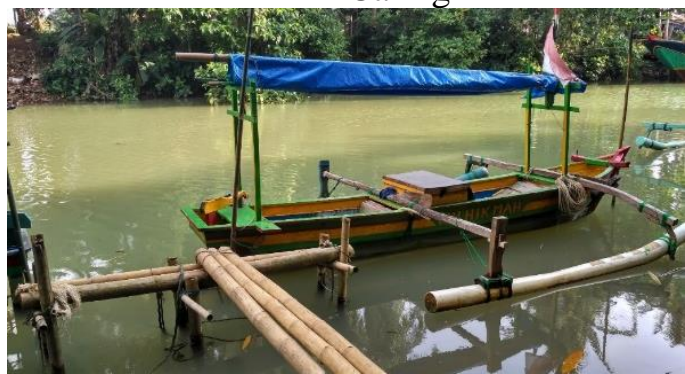

Gambar 6. Perahu Nelayan Bukan Cadik di Sungai Caringin

Pembuatan satu buah perahu bisa memakan biaya sekitar Rp.20.000.000,- sampai Rp.30.000.000,-, ini dianggap mahal oleh para nelayan tersebut sehingga kebanyakan dari mereka 
belum mempunyai perahu sendiri dan masih banyak yang ikut perahu orang lain, itu dikarenakan mahalnya harga perahu tersebut.

\subsubsection{Data Bahan Baku Jerigen Bekas}

Dengan demikian dicarilah bahan alternative, dengan mempertimbangkan kekuatan bahan serta ketahanan terhadap air laut.

Maka ditetapkanlah bahan tersebut adalah Jerigen Plastik bekas, dengan pertimbangan bahwa jerigen plastik bekas ini banyak sekali dan mudah didapatkan serta bahannya cukup kuat dan tahan terhadap air laut.

Bahan Baku Pembuatan jerigen adalah Polimer dimana polimer mempunyai struktur kekuatan sebagaimana terlihat pada tabel 1, kekuatan dari jerigen plastik ini adalah sangat kuat.

Tabel 1. Kekuatan Tarik, tekan, dan lentur bahan polimer

\begin{tabular}{lccccc}
\hline \multicolumn{1}{c}{ Polietilen } & $\begin{array}{c}\text { Kekuatan } \\
\text { tarik } \\
(\mathrm{MPa})\end{array}$ & $\begin{array}{c}\text { Perpan- } \\
\text { jangan } \\
(\%)\end{array}$ & $\begin{array}{c}\text { Modulus } \\
\text { elastik } \\
(\mathrm{GPa})\end{array}$ & $\begin{array}{c}\text { Kekuatan } \\
\text { tekan } \\
(\mathrm{MPa})\end{array}$ & $\begin{array}{c}\text { Kekuatan } \\
\text { lentur } \\
(\mathrm{MPa})\end{array}$ \\
\hline $\begin{array}{l}\text { Polietilen masa jenis } \\
\text { tinggi (HDPE) }\end{array}$ & $21-38$ & $15-100$ & $0,4-1,0$ & 22 & 7 \\
$\begin{array}{l}\text { Polietilen masa jenis } \\
\text { rendah (LDPE) }\end{array}$ & $7-14$ & $90-650$ & $1,4-2,4$ & - & - \\
\hline
\end{tabular}

Sumber : Basuki R. Suratno. 2003. Polimer and Composite

\section{Fiber Glass}

Bahan pengikat selain menggunakan mur-baut juga menggunakan fiber glass. Fiber glas digunakan sebagai pengikat antara jerigensatu dengan yang lainnya dan juga sebagai bahan pengisi antar celah jerigen sehingga tidak terdapat celah atau lubang antara jerigen.

Adapun bahan-bahan fiber glass yang digunakan adalah erosil, pigmen, resin, katalis, talk, mat, aseton, PVA, mirror, cobalt, mirror dan dempul.

\section{Data Pemodelan}

Pemodelan perahu perlu dilakukan sebagai data model perahu yang nantinya akan digunakan untuk analisa, pemodelan menggunakan program maxsurf modeler dengan ukuran dan bentuk sesuai dengan jumlah serta susunan jerigennya dimana jumlah jerigen yang dibutuhkan ada 31 buah jerigen untuk ukuran 30 liter. Setelah dimodelkan didapat ukuran pokok perahu sebagai berikut :

Panjang Keseluruhan (Loa) $=3,80 \mathrm{~m}$

Panjang antara garis tegak $(\mathrm{Lpp})=3,40 \mathrm{~m}$

Sarat Perahu $(\mathrm{T})=0,400 \mathrm{~m}$

Lebar Kapal $(B)=0,858 \mathrm{~m}$

Kecepatan dirancang $=6$ knot.

Hasil.

\section{Hambatan dan Power Perahu}

Perahu yang sudah dimodelkan di Maxsurf Modeler tersebut kemudian dianalisa menggunakan Maxsurf Resistance menggunakan metode KR Barge dikarenakan bentuk lambung perahu mendekat kotak, dari hasil Analisa didapatkan pada tabel 2.
Tabel2.Analisa,Kecepatan,Hambatan Power

\begin{tabular}{|r|c|c|c|c|c|}
\hline & $\begin{array}{c}\text { Speed } \\
\text { (KN) }\end{array}$ & $\begin{array}{c}\text { Froude } \\
\text { Number } \\
\text { (LWL) }\end{array}$ & $\begin{array}{c}\text { Froude } \\
\text { Number } \\
\text { (Volume) }\end{array}$ & $\begin{array}{c}\text { KR Barge } \\
\text { Resistance } \\
\text { (Newton) }\end{array}$ & $\begin{array}{c}\text { KR Barge } \\
\text { Power } \\
\text { (HP) }\end{array}$ \\
\hline 1 & 0 & 0 & 0 & -- & -- \\
\hline 2 & 0.2 & 0.018 & 0.032 & 0.93 & 0 \\
\hline 3 & 0.4 & 0.036 & 0.065 & 3.74 & 0.001 \\
\hline 4 & 0.6 & 0.053 & 0.097 & 8.41 & 0.003 \\
\hline 5 & 0.8 & 0.071 & 0.129 & 14.95 & 0.008 \\
\hline 6 & 1 & 0.089 & 0.162 & 23.36 & 0.016 \\
\hline 7 & 1.2 & 0.107 & 0.194 & 33.63 & 0.028 \\
\hline 8 & 1.4 & 0.125 & 0.226 & 45.78 & 0.044 \\
\hline 9 & 1.6 & 0.142 & 0.259 & 59.79 & 0.066 \\
\hline 10 & 1.8 & 0.16 & 0.291 & 75.67 & 0.094 \\
\hline 11 & 2 & 0.178 & 0.323 & 93.43 & 0.129 \\
\hline 12 & 2.2 & 0.196 & 0.356 & 113.04 & 0.172 \\
\hline 13 & 2.4 & 0.213 & 0.388 & 134.53 & 0.223 \\
\hline 14 & 2.6 & 0.231 & 0.42 & 157.89 & 0.283 \\
\hline 15 & 2.8 & 0.249 & 0.453 & 183.11 & 0.354 \\
\hline 16 & 3 & 0.267 & 0.485 & 210.21 & 0.435 \\
\hline 17 & 3.2 & 0.285 & 0.517 & 239.17 & 0.528 \\
\hline 18 & 3.4 & 0.302 & 0.55 & 270 & 0.633 \\
\hline 19 & 3.6 & 0.32 & 0.582 & 302.7 & 0.752 \\
\hline 20 & 3.8 & 0.338 & 0.614 & 337.27 & 0.884 \\
\hline 21 & 4 & 0.356 & 0.647 & 373.7 & 1.031 \\
\hline 22 & 4.2 & 0.374 & 0.679 & 412.01 & 1.194 \\
\hline 23 & 4.4 & 0.391 & 0.711 & 452.18 & 1.373 \\
\hline 24 & 4.6 & 0.409 & 0.744 & 494.22 & 1.568 \\
\hline 25 & 4.8 & 0.427 & 0.776 & 538.13 & 1.782 \\
\hline 26 & 5 & 0.445 & 0.808 & 583.91 & 2.014 \\
\hline 27 & 5.2 & 0.462 & 0.841 & 631.55 & 2.266 \\
\hline 28 & 5.4 & 0.48 & 0.873 & 681.07 & 2.537 \\
\hline 29 & 5.6 & 0.498 & 0.905 & 732.45 & 2.83 \\
\hline 30 & 5.8 & 0.516 & 0.938 & 785.71 & 3.144 \\
\hline 31 & 6 & 0.534 & 0.97 & 840.83 & 3.48 \\
\hline & & & & & \\
\hline
\end{tabular}

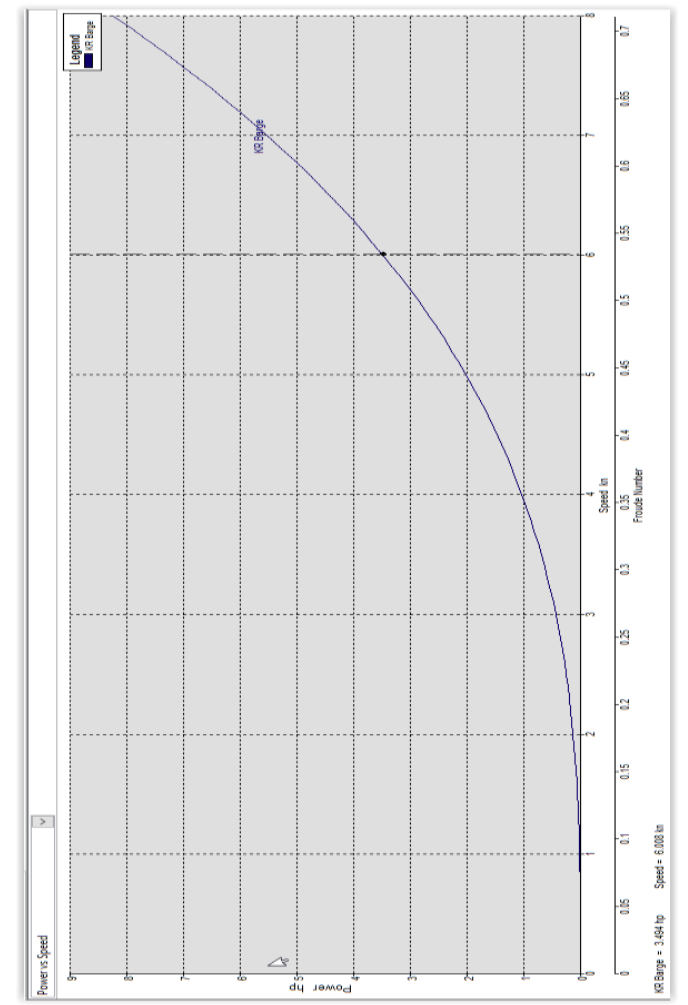

Gambar7. Grafik, kecepatan,Hambatan, Power

Berdasarkan hasil dari tabel 2 dan gambar 7 menunjukan bahwa besarnya Hambatan Perahu pada kecepatan 6 Knot adalah 840,83 Newton (N) sedangkan power perahu tersebut 3,48 Horse Power (HP).

Maka besarnya Efektif Horse Power adalah 3,48 HP, kemudian dapat dihitung :

DHP (Deliver Horse Power) $=5,658 \mathrm{HP}$

SHP (Shaft Horse Power) $=5,773 \mathrm{HP}$

BHPscr (Brake Horse Power) $=5,891 \mathrm{HP}$

BHPmcr (BrakeHorsePower $)=6,931 \mathrm{HP}$ 
Digunakan Mesin yang ada dipasaran sebesar $8 \mathrm{HP}$ dengan spesifikasi terlihat pada gambar 8 .

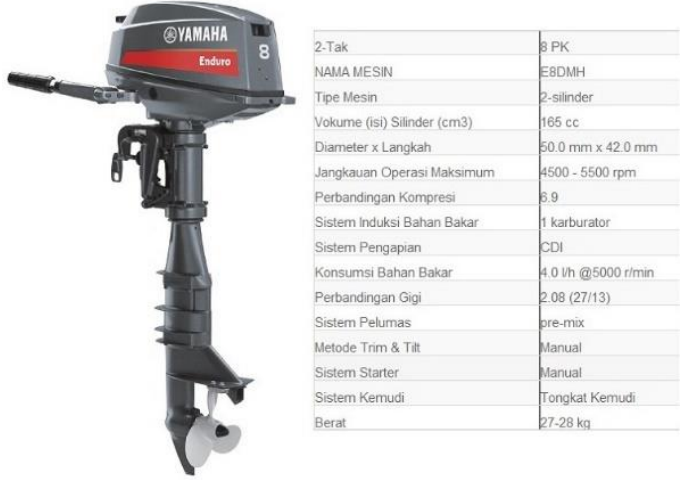

Gambar 8. Mesin Outboard 8 HP

\section{Besarnya Muatan Perahu}

Perahu yang sudah dimodelkan di Maxsurf Modeler tersebut bisa dianalisa dari Data Kurva Hidrostatik gambar 9 untuk sarat air perahu 0,4 meter didapat displacementnya adalah $1130 \mathrm{~kg}$.

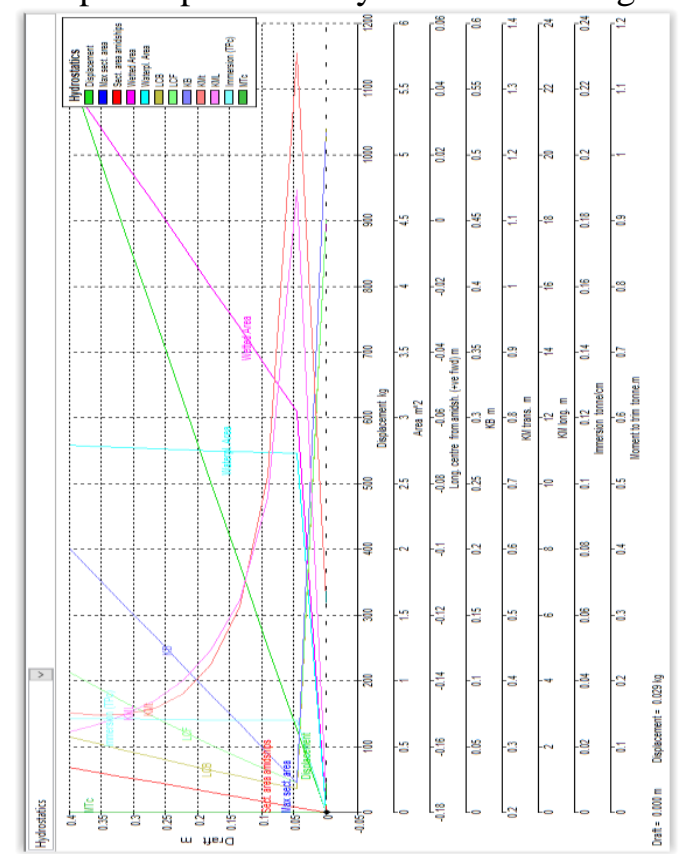

Gambar 9. Kurva Hidrostatik Perahu

Kemudian dihitung Berat Light Weight Tonnage (LWT) didapatkan hasil 135,5 kg.

Serta dihitung muatannya, karena muatan termasuk unsur Dead Weight Tonnage (DWT) maka dihitung terlabih dahulu unsur DWT lainnya, setelah itu didapat muatan yang dapat diangkut Perahu adalah sebesar $655,5 \mathrm{~kg}$.

\section{Stabilitas Perahu}

Perahu yang sudah dimodelkan di Maxsurf Modeler tersebut bisa dianalisa dengan menggunakan Maxsurf Stability sebagaimana ditampilkan pada gambar 10. untuk mengetahui stabilitas perahu tersebut. Setelah dimasukan ke Maxsurf Stability maka didapatkan hasil Kurva Silang (Cross Curve) dilihat hasilnya pada gambar 11 .

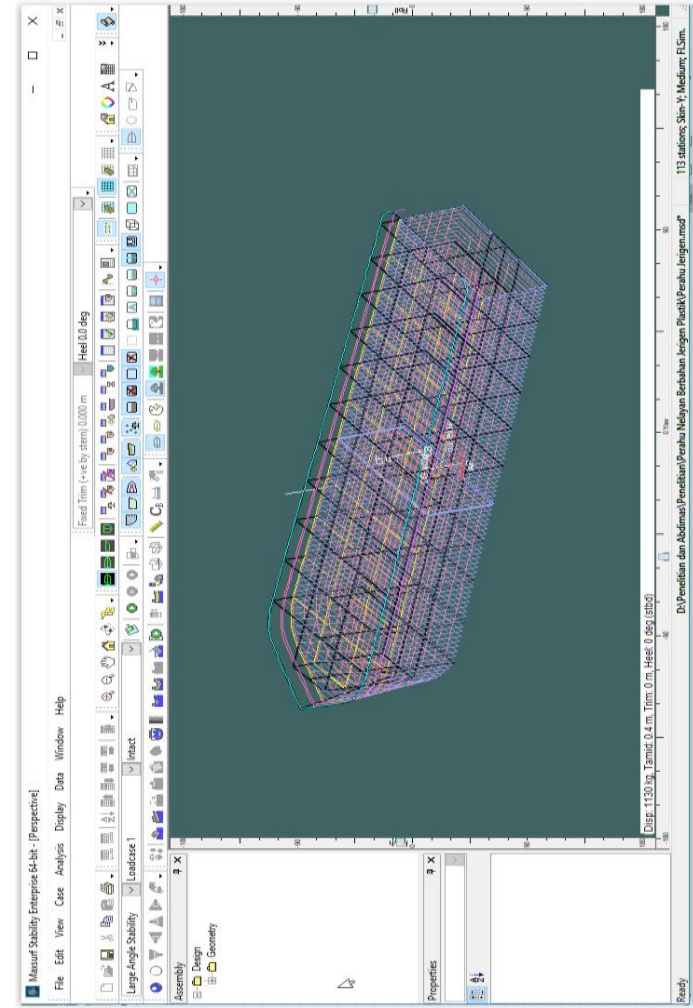

Gambar 10. Perahu dianalisa Stabilitas

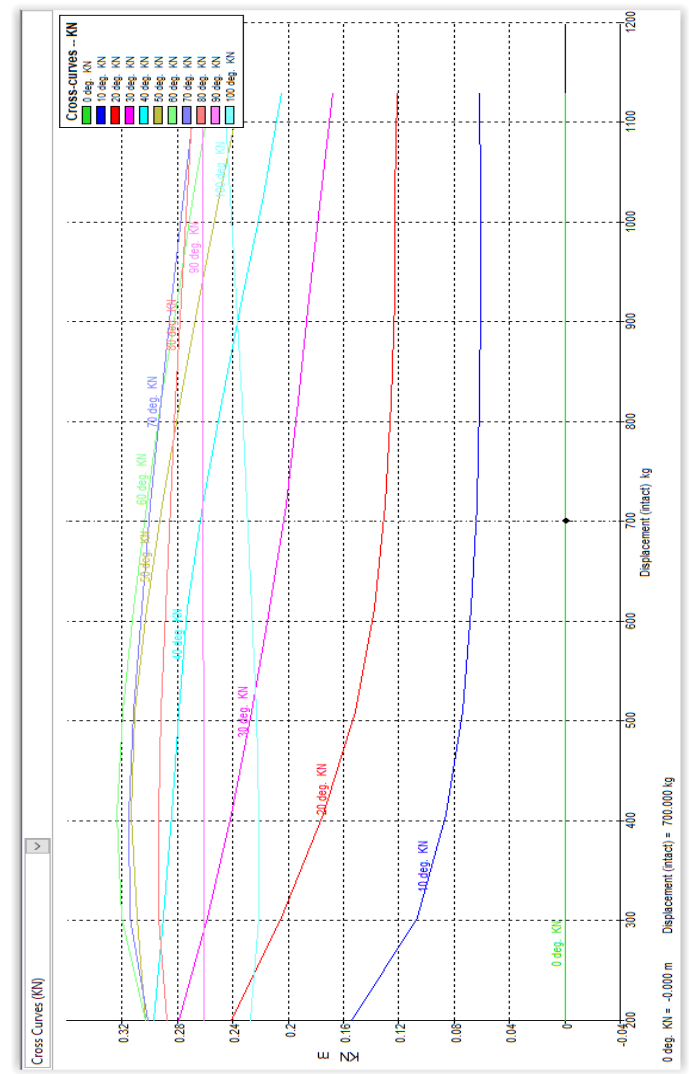

Gambar 11. Kurva Silang (Cross Curve)

Dari Kurva Silang tersebut pada gambar 11, dapat dibuat kurva stabilitas perahu perkondisi, baik kondisi kosong/tanpa muatan (Empty Load) diperlihatkan pada gambar 12, kondisi muatan penuh (full load) sebagaimana ditampilkan pada gambar 13. Jadi dengan adanya kurva silang kita dapat 
mengetahui stabilitas dalam berbagai macam kondisi muatan.

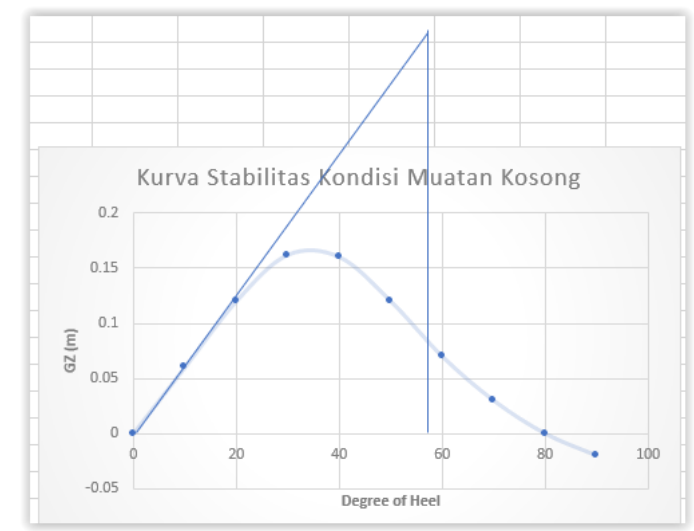

Gambar 12. Kurva Stabilitas Perahu Muatan Kosong.

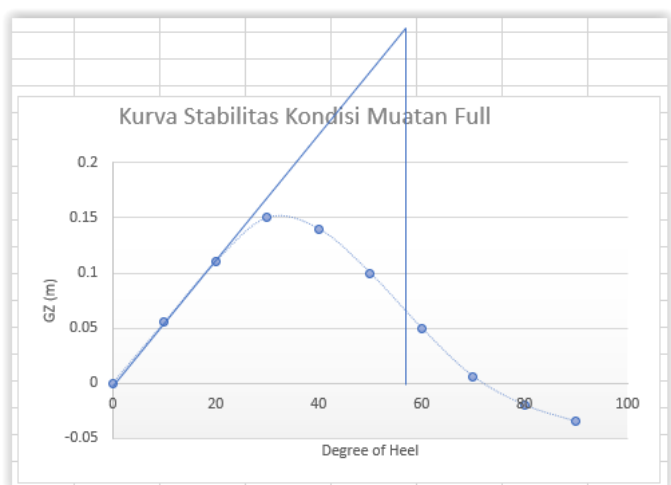

Gambar 13. Kurva Stabilitas Perahu Muatan Full Load.

Hasil Stabilitas perahu pada kondisi muatan kosong (Empty Load) sebagaimana terlihat pada gambar 12 maupun pada kondisi muatan penuh (Full Load) pada gambar 13. Menunjukan bahwa stabilitas perahu nelayan tersebut sangat baik artinya apabila perahu oleng atau miring akibat ombak, angin atau muatan maka perahu tersebut dapat kembali keposisi tegak sehingga perahu tidak tenggelam.

Manufaktur Model Perahu

Adapun pembuatan manufaktur model Perahu Nelayan menggunakan jerigen plastik bekas untuk meningkatkan kesejahteraan nelayan Dapat dilihat pada gambar 14 .

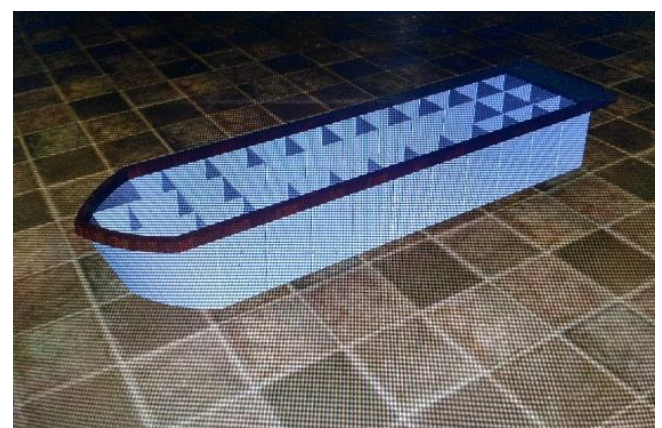

Gambar 14. Manufaktur Model Perahu

\section{DAFTAR PUSTAKA}

Adji W, Suryo, [2005], Engine Propeller Matching.

Barras, C.B. and Derret, D.R., 2006, "Ship Stability for Masters \& Mates”, sixth edition.

Jacklyn Fiorentina, T. TINJAUAN HUKUM

LAUT INTERNASIONAL MENGENAI PERLINDUNGAN HUKUM NELAYAN TRADISIONAL INDONESIA.

Diss. Universitas Udayana, 2015.

Monintja, D., and Roza Yusfiandayani.

"Pemanfaatan Sumber Daya Pesisir dalam Bidang Perikanan Tangkap." Bogor, 29 Oktober-3 November 2001 (2001): 56.

IMO, Intact Stability Code, IntactStability for All Types of Ships Covered by IMO Instruments. London, UK: IMO.

Molland, A.F., Turnock, R.S. and Hudson, D.A., 2011, "Ship Resistance and Propulsion: Practical Estimation of Propulsive Power", Cambridge University Press.

Rule Biro Klasifikasi Indonesia, Volume VII, 2013

Regulations for the Classification and Construction of Fibre Reinforced Plastics

Sv.Aa Harvald, [1992], Tahanan dan Propulsi Kapal, Airlangga University Press, Surabaya.

Taggart, Robert, Ed . 1980 . Ship Design and contruction. The Society of Naval Architect \& Marine Engineers.

Taylor, [1972], Principle Of Naval Architecture Vol.II, The society of Naval \& Marine Engineering, New York.

Xuebin, L., 2009, "Multi objective

Optimization and Multi attribute Decision Making Study of Ship's

Principal Parameters in

Conceptual Design", Journal of Ship

Research, Vol. 53, No. 2, June, pp. 83-92.

Workboat, Biro Klasifikasi Indonesia, 2003. 